\title{
Contribution of Principal Supervision, Principal Leadership, and Work Motivation on Performance of Private Vocational High Schools Teachers in Tanah Bumbu Regency
}

\author{
Linda Normasari *, H. Rustam Effendi, Metroyadi \\ Master Program of Education Management, Universitas Lambung Mangkurat, Banjarmasin 70123, \\ Indonesia
}

\author{
Article history: \\ Submission August 2020 \\ Revised September 2020 \\ Accepted October 2020 \\ ${ }^{*}$ Corresponding author: \\ E-mail: \\ lindanormasari@gmail.com
}

\begin{abstract}
The success of schools in producing quality graduates cannot be separated from the performance of the teachers. Thus, variables that can support teacher performance need to be identified to make it easier for policymakers to prepare activities or programs to improve teacher performance. Theoretically, various variables are assumed to have a relationship with teacher performance. To see whether this variable is proven to have a significant effect, an empirical test is necessary. This study analyzes several variables theoretically believed to have a relationship with the performance of teachers. Those variables include the principal's supervision, the school principal's leadership, and work motivation on the performance of Private Vocational High School teachers in Tanah Bumbu Regency. This research uses a descriptive quantitative method. A sample of 67 people was selected from 207 teachers. The data were collected using a valid and reliable questionnaire and analyzed using Path Analysis. The results showed that: (1) A direct contribution between the supervision of the principal, leadership, work motivation, and teacher performance (2) There is a contribution of principal supervision and work motivation to the performance of Private Vocational High School teachers in Tanah Bumbu Regency (3) There are a principal contribution leadership and work motivation on the performance of Private Vocational High Schools teachers in Tanah Bumbu Regency. The results obtained vary in terms of the contribution and significance of all the variables studied.
\end{abstract}

Keywords: Principal leadership, principal supervision, teacher work motivation

\section{Introduction}

Human resources quality has a critical role in a country. The quality of human resources is proven to affect a country (Kotásková, et al., 2018). Countries with good quality human resources tend to have the right level of the economy, and vice versa, countries with lowquality human resources tend to have a lower economic level. So, it means the improvement of the workforce quality of a country will improve that country's economy.
Workforce quality enhancement is strongly influenced by education quality (lonescu, 2012; Naylor \& Sayed, 2014). The quality of education personnel will significantly influence the quality of further education. It is because the teaching staff's quality will affect the quality of graduates produced by these educational institutions (DarlingHammond, 2000). Teachers who have good quality are proven to have a significant contribution to their students' learning achievement

How to cite:

Normasari, L. (2020). Contribution of principal supervision, principal leadership, and motivation on performance of private vocational high schools teachers in Tanah Bumbu regency. Journal of K6, Education, and Management, 3 (2), 187 - 195. doi: 10.11594/jk6em.03.02.10 
(Canalesa \& Maldonado, 2018). Thus, increasing teachers' quality will affect improving the quality of student learning outcomes (Harris \& Sass, 2011). This explanation said that as a profession closely related to education, the teaching profession is the spearhead of developing quality and superior human resources.

The quality of a teacher can be seen from their performance. Given that the teacher's main task is teaching, teacher performance is related to planning, implementing, and evaluating learning. To be able to carry out learning well, many things must be done by a teacher. In carrying out their duties, the teacher must choose the right learning strategy, know student learning styles, and know students' competence (Dybowski, Sehner, \& Harendza, 2017; Muelasa \& Navarroa, 2015). The main characteristic of the successful formation of qualified and superior teachers is the realization of quality education, whose operations are shown in learning activities. Thus, teacher performance strongly influences the realization of quality national education (Sagala, 2017). Besides, teacher performance will ensure that schools can develop in a sustainable manner (Bichi, 2017).

However, according to Sulisworo, Nasir, \& Maryani (2017), teachers' performance in Indonesia is still not optimal. A survey conducted by UNESCO for the quality of teacher performance in Indonesia, which is at level 14 out of 14 developing countries (UNESCO, 2018), supports this. These results indicate that the teaching performance of teachers in Indonesia is still not per their aspirations

The factors that can affect a person's performance are very complex. These factors include training and work experience, education, personality attitudes, organization, leaders, social conditions, individual needs, physical conditions of the workplace, abilities, and work motivation (Wijania, 2017).

Furthermore, according to (2015), factors that affect teacher performance include education level, teaching supervision, upgrading programs, conducive climate, facilities and infrastructure, physical and mental conditions of teachers, principal leadership style, welfare assurance, and principals' managerial ability.
A school principal is expected to have the ability to become someone who can move, direct, influence, and empower the mindset and work methods of teachers and school staff to be independent in work (Suhaimi, 2018). Based on the perspective of national education policy (Department of National Education, 2006), there are seven leading roles of school principals, namely: educator (educator), manager; administrator; supervisor (supervisor); leader (leader); work climate creator; and entrepreneurs. As a supervisor, the principal's role is significant in improving and enhance teacher teaching performance. Thus, school principals should be active in conducting supervision, both managerial and academic supervision.

The principal's leadership has a great impact on the productivity of the teachers. Theoretically, for school leaders or school principals, it can be seen that the principal has an essential role in supporting teacher performance. The principal's role is to manage quality educational institutions according to predetermined standards (Metroyadi, 2015), namely by providing guidance, direction, creation, supervision, and predicting them to do their job correctly. Therefore, through leadership learning, the principal can motivate and empower teachers to create the right work motivation and can act as a teacher who has a professional attitude besides the teacher himself who can improve the quality of his work (Rizqan, 2019). Supervision is also vital for school principals because it can help teachers in schools to jointly realize school goals and national education goals (Rijani et al., 2018).

A school principal's leadership will also be a role model for all school members, teachers, employees, and students. Good leadership that can make teachers feel comfortable and motivated to work is believed to increase teacher productivity and performance (Ma \& Marion, 2019). Furthermore, teachers who feel comfortable and have high performance will help students achieve the expected learning achievement (Ross \& Gray, 2006). So, it can be said that the principal's leadership will indirectly affect student achievement (Shatzer, Caldarella, Hallam, \& Brown, 2014). 
Four indicators must be met for the principal to be successful in carrying out his duties, namely: (1) Openness, (2) Attention to teachers and school staff, (3) Interaction, and (4) Decision Maker. Principals can increase teacher motivation by: (1) Implementing open management, (2) Implementing clear job descriptions and functions, (3) Implementing downward vertical relationships, (4) Mapping programs and activities to increase work motivation, (5) Continuous and comprehensive supervision, (6) Evaluation (Suriansyah, 2015).

In addition to principal leadership, according to Wardana (2008), work motivation has a significant relationship with teacher performance. The ones who are highly motivated normally will work harder than those who are less motivated. According to Rasto \& Maulani (2019), teacher motivation is one of the factors that play an essential role in teacher performance. Also, teacher work motivation on performance can be seen from the relationship between teacher work motivation and student achievement. Teachers who have high work motivation tend to do their job better, so teachers with higher motivation can usually deliver their students to achieve better learning achievement (Wilson \& Gardner, 2009; Poernamawijayai, Sulaiman, Suriansyah, \& Dalle, 2018). If all teachers are motivated, that will help the schools to achieve their visions and missions.

Considering the importance of teacher performance, teacher performance problems, the principal's role, and work motivation, this study is to determine the effect of leadership, supervision, and work motivation on teacher performance in Private Vocational High School in Tanah Bumbu Regency. Hopefully, this research will help policymakers prepare programs or activities related to improving teacher performance.

\section{Material and Methods}

The study population was 207 teachers of Private Vocational High School in Tanah Bumbu Regency. The research sample was 67 teachers who were selected by stratified proportional random sampling. Data were collected using questionnaires form of a Likert scale with alternative answers, a score of 1 to 5 , which are already valid and reliable. In this study, the questionnaires used to collect the data are the principal's supervision questionnaire, the principal's leadership, work motivation, and the teacher performance questionnaire. By the conceptual relationship model between variables, as shown in Figure 1.

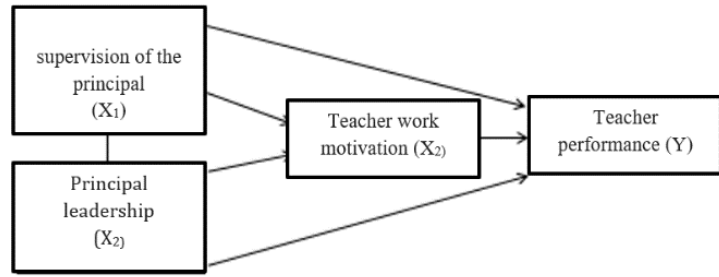

Figure 1. Research model

\section{Results and Discussion}

Interpretation of the path analysis results after going through the required analysis testing phase with a summary of the results shown in Tables 1 and 2.

Table 1.The result of path analysis in structure model 1

Structural 1 Principal Supervision, Principal Leadership Against Work Motivation

\begin{tabular}{llrl}
\hline Variable & Path coefficient & $t$ & Sig \\
\hline Supervision of the Principal & 0.280 & 5.719 & 0.000 \\
\hline Principal Leadership & 0.319 & 2.252 & 0.028 \\
\hline
\end{tabular}


Table 2. Result of path analysis in structure model 2

Structural 1 Principal Supervision, Leadership, Work Motivation, Against Teacher Performance

\begin{tabular}{lccc}
\hline Variable & Path coefficient & $t$ & Sig \\
\hline Supervision of the Principal & 0.582 & 5.795 & 0.000 \\
\hline Principal Leadership & 0.629 & 5.411 & 0.000 \\
\hline Work motivation & 0.500 & 4.974 & 0.000 \\
\hline
\end{tabular}

Table 3. Summary of hypothesis testing decisions $\mathrm{H}_{1}, \mathrm{H}_{2}, \mathrm{H}_{3}, \mathrm{H}_{4}$, and $\mathrm{H}_{5}$

\begin{tabular}{lll}
\hline $\mathrm{H}_{1}:$ There is a direct relationship between principal supervision to & sig & Decision \\
teacher work motivation & 0.000 & received \\
\hline $\begin{array}{l}\mathrm{H}_{2}: \text { There is a direct relationship between principal leadership to } \\
\text { teacher work motivation }\end{array}$ & 0.000 & received \\
\hline $\begin{array}{l}\mathrm{H}_{3}: \text { There is a direct relationship between principal supervision to } \\
\text { teacher performance }\end{array}$ & 0.000 & received \\
\hline $\begin{array}{l}\mathrm{H}_{4}: \text { There is a direct relationship between principal leadership to } \\
\text { teacher performance }\end{array}$ & 0.000 & received \\
\hline $\begin{array}{l}\mathrm{H}_{5}: \text { There is a direct relationship between work motivation to teacher } \\
\text { performance }\end{array}$ & 0.000 & received \\
\hline
\end{tabular}

Table 4. Summary of hypothesis testing decisions $\mathrm{H}_{6}$ and $\mathrm{H}_{7}$

\begin{tabular}{llll} 
Hypothesis & \multicolumn{2}{l}{ Path coefficient } & \multirow{2}{*}{ Decision } \\
\cline { 2 - 3 } $\mathrm{H}_{6}:$ There is an indirect relationship of principal & & & \\
supervision to teacher performance through teacher & 0.584 & 0.141 & Received \\
work motivation & & & \\
\hline $\mathrm{H}_{7}:$ There is an indirect relationship of principal & & & \\
leadership to teacher performance through teacher & 0.557 & 0.141 & Received \\
work motivation & & &
\end{tabular}

As shown in Table 1 and Table 2, the results of the path analysis are used to answer the five research hypotheses that have been formulated. Table 3 shows the decision taken based on the statistical analysis results. It is the summary of the decision on hypothesis 1 to hypothesis 5 with a significance value of less than 0.05 . Table 4 summarizes the decision on hypothesis testing 6 to hypothesis 7 , which is an indirect effect. Based on the table above analysis results, the relationship between variables could be explained as follows.

\section{Relationship of principal supervision, principal leadership to teacher work moti- vation}

Based on the hypothesis testing results, the value of Sig $<0.05$ was obtained so that $\mathrm{HO}$ was rejected. It shows a significant effect of principal supervision on vocational school teachers' work motivation in Tanah Bambu. The correlation test results show that $R^{2}(R$ Square) is 0.072 , which means that the relationship of the principal's supervision to Private Vocational High School teachers' work motivation in Tanah Bumbu Regency is $7.2 \%$. It is in line with research (Anggriani, 2010) that there is a significant relationship between the supervision of the principal and teachers' work motivation.

One definition of supervision refers to the term principal's supervision in providing a stimulus so that someone has the will to carry out an activity to achieve goals. One of the forms of work motivation is if there is encouragement from within or stimulation from outside. One form of external stimulation that can encourage the formation of work motivation is supervision. One of the principal's general supervision functions is to make efforts to grow 
and stimulate teachers and other school employees to carry out their duties as mandated as possible. Supervision carried out actively by the principal will indirectly also create a sense of belonging to the teachers towards their work at school, which comes from being cared for and respected by the leaders.

Research conducted by Sudirjo (2013) also proved that supervision positively and significantly affected teacher work motivation. According to him, the ability to carry out supervision will be very influential in increasing teacher work motivation.

The results of hypothesis testing show a direct relationship of the principal's leadership to Private Vocational High School teachers' work motivation in Tanah Bumbu Regency. The regression test results show that each increase of one principal's leadership score will increase the teacher's work motivation score by 0.319 and vice versa if a decrease in the principal's leadership score will decrease the teacher's work motivation score 0.319 . This result is in line with Nasrun (2016), which states that principal school leadership has a significant influence on work motivation. Muttaqin's research (2010) also found that principal leadership positively influences teacher work motivation in the moderate or moderate category.

Principal leadership is related to the formation of teacher work motivation and other school support elements. Teacher work motivation can be grown through the principal's leadership function to regulate the physical environment, regulate the work atmosphere, discipline, encourage, reward adequately, and provide a learning resource center through the development of a learning resource center (Nasrun, 2016). Septian, Ngadiman, \& Ivada (2013), in their research, also proved that there was a positive influence which showed that quality leadership of the principal improve the work motivation. Sudirjo (2013) also found that principal leadership affects teacher work motivation. Likewise, Abubakar, Inuwa, \& Hamma (2018) found that principals' leadership style in high schools in Nigeria has a significant effect on teacher work motivation. A leader can be successful if he gets support from subordinates, and subordinates are motivated to work with the leader in achieving organizational goals. Therefore, leaders need to make efforts so that their subordinates are always motivated at work. Febriani (2019), through his research, proves that there is a relationship between the principal's transformational leadership and teacher work motivation, which can be seen from the path coefficient value of 0.367 . It is proven that the principal can make a direct relationship to providing motivation, inspiration, and ideas to teachers. It means that work motivation or work motive is a reflection of personal attitudes and attitudes towards work and collaboration, such as attitudes towards each employee. Motivation is, to some extent, influenced by the factors of the leader.

Besides, several studies also show that leadership affects performance. Based on Joo (2020), it was found that leadership style was proven to affect high school teachers' performance in Korea. Research conducted by Imhangbe, Okecha, \& Obozuwa (2018) also found that leadership style affects teacher performance. The implementation of different leadership styles by the principal will have a different effect on teacher performance.

\section{Relationship of principal supervision, principal leadership, work motivation to teacher performance}

From the hypothesis testing, the value of $\mathrm{Sig}<0.05$ was obtained so that $\mathrm{HO}$ was rejected. This shows that there is a direct relationship of principal supervision to private vocational school teachers' performance in Tanah Bumbu Regency. The correlation test results show that the coefficient of determination R2 ( $R$ Square) is 0.341 , which means that the relationship of principal supervision to the performance of private vocational school teachers in Tanah Bumbu Regency is $34.1 \%$.

This study's results are similar to the research of Ariana, Dantes, \& Lasmawan (2015), which states that the principal supervision makes a substantial relationship to the performance of the teachers. Furthermore, they also found that the principal's education supervision contributed $35.49 \%$ to teacher 
performance. One of the parties most needed to help boost teacher performance is the principal. Supervision of the principal plays a role in providing services and guidance to teachers and also school components. Through supervision, teachers are allowed to improve performance, are trained to solve problems at hand. Through supervision, a teacher can understand his professionalism as a teacher so that he can do assignments properly.

Suhaimi \& Wardaniah (2017), through their research, prove that there is a positive relationship between the supervision of the principal and the performance of public elementary school teachers in Tanjung Regency with a correlation coefficient of 0.252 . Because the correlation coefficient obtained is greater than 0.05 and the significant level (Sig) is $0.025<$ than $0.05<$ than 0.05 . This study confirms if they are related to previous relevant research, namely, research conducted by Ernilawati (2011), in her thesis entitled "The Relationship Between Principal Supervision and Achievement Motivation on Teacher Performance at the Extraordinary Middle School throughout Banjar Regency.

Rahmatullah (2019) significantly shows that his research shows that the principal's supervision contributes to the performance of teachers at the High School in Barito Kuala, with a determination value of $66.1 \%$. Supervision carried out by the principal in learning planning and learning implementation is proven to improve teachers' ability to carry out the learning process to positively impact student learning outcomes. So, it can be said that if the principal has properly supervised each teacher, the competence of the teachers in the school will be better too. Besides, quality supervision is also proven to increase teachers' creativity in carrying out their duties in the teaching and learning process (Jain \& Jain, 2016).

The results of hypothesis testing show the score of Sig $<0.05$ was obtained. This shows a direct relationship of the principal's leadership to the performance of private vocational school teachers in Tanah Bumbu Regency. The correlation test results show that the coefficient of determination $R 2$ ( $R$ Square) is 0.311 , which means that the relationship of the principal's leadership to the performance of private vocational school teachers in Tanah Bumbu Regency is $31.1 \%$. Nasrun's (2016) research also found that principal leadership has a positive effect on teacher performance.

Good principal leadership can strive to improve teacher performance through education, staff capacity building programs (Sobirin, 2012). Therefore, the principal must have the personality or traits and abilities and skills to lead an educational institution.

Similar to the research (Suarsana, 2009), there is a strong relationship between leadership and teacher performance. Septian, Ngadiman, \& Ivada (2013) also found something similar to the $t_{\text {table }}$ at the $5 \%$ significance level of 1.993. because of the value of $t$ count $>t$ table $(2.468>1.993)$ with $P<0.05$, which proves that the leadership of the principal brings a positive impact on teachers' performance. Sudirjo's (2013) research results also show that the principal's leadership affects teacher performance. The principal, the highest leader who is very influential and determines the school's progress, must be fluent with administrative skills, have a high commitment, and be flexible in carrying out his duties. Good principal leadership must be able to strive to improve teacher performance through education, staff capacity building programs.

Based on the hypothesis testing, it shows that teacher work motivation has a robust relationship to the private vocational school teachers' performance in Tanah Bumbu Regency. The correlation test results show that the coefficient of determination R2 ( $R$ Square) is 0.276 , which means that the relationship of teacher work motivation to the performance of Private Vocational High School teachers in Tanah Bumbu Regency is $27.6 \%$.

It is in line with Ningsih (2017) research, which states that there is a significant effect of work motivation on teacher performance, with a $23.7 \%$ relationship. Suwedana's research (2013) also found a significant correlation between achievement motivation and teacher performance with $r$ count $=0.276$, an active relationship of $7.42 \%$, and a determination of $7.60 \%$. Fostering teachers' motivation is very important because the teacher is one of the 
components in teaching and learning activities, which has a vital role in determining learning success. Likewise, with Franky (2019), who found that the direct effect of employee motivation on the performance of the Integrated Service Unit of Education and Culture Service employees in Murung Raya Regency was $7.30 \%$. Work motivation will make someone more enthusiastic in doing their job (Kelimeda et al., 2018).

The relationship of principal supervision, principal leadership, work motivation to teacher performance through teacher work motivation

Correlation test analysis concludes that principal supervision is a determining variable for a teacher's performance who has work motivation because the direct influence coefficient's value is higher than the value of the indirect effect coefficient. The coefficient of determination $R 2$ 's (R Square) value is 0.487 . It means that the indirect relationship of principal supervision to teacher performance through the work motivation of SMKS teachers in Tanah Bumbu Regency is $48.7 \%$. Yanes (2012) also found a positive and significant relationship between principal supervision and achievement motivation with teacher performance, meaning that the better the teacher's perception of the principal's supervision and the teacher's work discipline, the better the performance. Based on the results of testing the final hypothesis, it shows an indirect relationship of the principal's leadership to teacher performance through the teachers' work motivation at Private Vocational High School in the Regency of Tanah Bumbu. The correlation test scores show that the coefficient of determination R2 (R Square) is 0.462 , which means that the indirect relationship of the principal's leadership to teacher performance through the work motivation of Private Vocational High School teachers in Tanah Bumbu Regency is $46.2 \%$. In comparison, the regression equation of principal leadership on teacher performance through private vocational school teachers' work motivation in Tanah Bumbu Regency is $Y=38.911+0.506$ $\mathrm{X} 2+0.385 \mathrm{Z}$. In line with Firmawati's research (2017), which states that there is a significant influence between the principal's leadership and work motivation on teacher performance is $96.8 \%$. The two variables, namely principal leadership and work motivation, go hand in hand with the teacher performance variable, meaning that the higher quality of the principal's leadership and work motivation, the higher the teacher's performance. Handayani's research (2015) also found that the principal's leadership style and teacher work motivation significantly affected teacher performance.

\section{Conclusion and Recommendation}

Based on the data from the research conducted, it can be concluded that: 1) there is a relationship of principal supervision to teacher work motivation; 2) there is a relationship of the principal's leadership to teacher work motivation; 3 ) there is a relationship of principal supervision to teacher performance; 4) there is a relationship of the principal's leadership to teacher performance; 5 ) there is a relationship of teacher work motivation to teacher performance; 6 ) there is an indirect relationship of principal supervision to teacher performance through teacher work motivation, and 7) there is an indirect relationship of principal leadership to teacher performance through teacher work motivation. This study shows that the principal's supervision, principal leadership, and work motivation directly affect performance. Also, work motivation can be a variable that mediates the supervision of the principal and the leadership of the principal to influence performance. It is suggested that several related parties consider improvements that could affect teachers' performance, which will impact the quality of Private Vocational High School education in Tanah Bumbu Regency. Besides, teacher performance is also influenced by various other factors. Other researchers are advised to conduct research similar to this research by raising the same variables in different places and can use this research as literature and a source of information for further research in the field of education. Besides, other researches that analyze other variables that may influence the teachers' performance should also be conducted. 


\section{Acknowledgment}

Our gratitude and appreciation go to all parties involved and contributed to completing this research.

\section{References}

Abubakar, A.-M., Inuwa, B. B., \& Hamma, M. (2018). Principal leadership style towards teachers' motivation on secondary schools in Nigeria. Advances in Social Science, Education and Humanities Research, 125, 8890. doi:10.13140/RG.2.2.22288.30

Anggriani, N. (2010). Contribution of principal supervision and teacher work motivation to teacher teaching performance (At SMAN throughout Indragiri Hulu Regency, Riau Province). Jurnal Administrasi Pendidikan, 12(1), 1-5.

Ariana, I. W., Dantes, N., \& Lasmawan, I. W. (2015). Contribution of school principal supervision, achievement motivation and work commitment to teacher performance in the VIII school cluster, Abang District. Jurnal Pendidikan Dasar Ganesha (e-Journal Program Pascasarjana Universitas Pendidikan Ganesha), 1-11.

Bichi, A. A. (2017). Evaluationof teacher performancein schools: Implication for sustainable development goals. Northwest Journal of Educational Studies, 2(1), 103-113.

Canalesa, A., \& Maldonado, L. (2018). Teacher quality and student achievement in Chile: Linking teachers' contribution and observable characteristics. International Journal of Educational Development, 60, 33-50. doi:https://doi.org/10.1016/j.ijedudev.2017.09.009

Darling-Hammond, L. (2000). Teacher quality and student achievement:a review of state policy evidence. Education Policy Analysis Archives, 8(1), 1-44.

Department of National Education. (2006). Teachers' competency standards. Jakarta: Depdiknas.

Dybowski, C., Sehner, S., \& Harendza, S. (2017). Influence of motivation, self-efficacy and situational factors on the teaching quality of clinical educators. BMC Medical Education, 17(1), 84-95. doi:https://doi.org/10.1186/s12909-017-0923-2

Ernilawati. (2011). The relationship between principal supervision and achievement motivation on the performance of SMPLB teachers in Banjar Regency. Banjarmasin: FKIP UNLAM.

Febriani, H., Aslamiah, \& Saleh, M. (2019). Contribution of school principal transformational leadership, work motivation through job satisfaction for OCB teachers. Jurnal o K6 Education and Management Vol.2 No.4.

Franky, E. W. (2019). The influence of transformational leadership, work motivation and work commitment to the employee performance of the UPT Disdikbud Murung
Raya Regency. Jurnal of K6 Education and Management (j-K6EM), 2(2), 40-45.

Handayani, T. \&. (2015). The influence of principal leadership, teacher motivation and organizational culture on teacher performance at SMA Negeri Wonosobo. Jurnal Akuntabilitas Manajemen Pendidikan, 3(2), 264-277.

Harris, D. N., \& Sass, T. R. (2011). Teacher training, teacher quality and student achievement. Journal of Public Economics, 95(7-8), 798-812. doi:https://doi.org/10.1016/j.jpubeco.2010.11.009

Imhangbe, O. S., Okecha, R. E., \& Obozuwa, J. (2018). Principals' leadership styles and teachers' job performance: Evidence from Edo State, Nigeria. Educational Management Administration and Leadership, 47(6), 909-924. doi:https://doi.org/10.1177/1741143218764178

lonescu, A. M. (2012). How does education affect labour market outcomes? Review of Applied Socio- Economic Research, 4(2), 130-144.

Jain, R., \& Jain, C. (2016). Employee Creativity: A Conceptual Framework. Management Labour Studies, 41(4), 294313. doi:10.1177/0258042X16676664

Joo, Y. H. (2020). The effects of distributed leadership on teacher professionalism: The case of Korean middle schools. International Journal of Educational Research, 99, 1-14. doi:https://doi.org/10.1016/j.ijer.2019.101500

Kelimeda, Hairudinor, Ridwan, M. N., \& Dalle, J. (2018). the effect of motivation, job satisfaction and job disciplinetoward employee performance of PT. Buma Perindahindo at Lng Tangguh Site, Teluk Bintuni Regency, West Papua, Indonesia. European Journal of Human Resource Management Studies, 2(1), 49-73. doi:http://dx.doi.org/10.5281/zenodo.2040456

Kotásková, S. K., Procházka, P., Smutka, L., Maitah, M., Kuzmenko, E., Kopecká, M., \& Hönig, V. (2018). The impact of education on economic growth: The case of India. Acta Universitatis Agriculturae Et Silviculturae Mendelianae Brunensis, 66(1), 253-261. doi:https://doi.org/10.11118/actaun201866010253

Ma, X., \& Marion, R. (2019). Exploring how instructional leadership affects teacher efficacy: A multilevel analysis. Educational Management Administration and Leadership, 20(10), 1-20. doi:10.1177/1741143219888742

Muelasa, A., \& Navarroa, E. (2015). Learning strategies and academic achievement. Procedia - Social and Behavioral Sciences, 165, 217- 221. doi:10.1016/j.sbspro.2014.12.625

Muttaqin, M. E. (2010). The influence of the principal's leadership on the Islamic Elementary School Roushon 
Fikr Jombang teachers' work motivation. Surabaya: Digital Library UIN Sunan Ampel.

Nasrun. (2016). The influence of the principal's leadership on work motivation and teacher performance. IImu Pendidikan Jurnal Kajian Teori dan Praktik Kependidikan, 1(2), 63-70.

Naylor, R., \& Sayed, Y. (2014). Teacher quality: Evidence review. Canberra: Department of Foreign Affairs and Trade.

Poernamawijayai, L. W., Sulaiman, Suriansyah, A., \& Dalle, J. (2018). contribution on supervision of supervisor, principals motivation, kindergarten teacher performance to improving the kindergarten quality in West Banjarmasin, Indonesia. European Journal of Alternative Education Studies, 3(2), 129-146. doi:10.5281/zenodo.2261031

Rahmatullah, M. S. (2019). Contribution of the Principa Supervision and Work Motivation on Teacher Perormance at Public High Scholl in Barito Kuala District. Journal of K6, Education, and Management (J-K6EM), 2(2), 118-125.

Rasto, \& Maulani, S. Y. (2019). Satisfaction and motivation as determinants of teacher performance. Jurnal Pendidikan Bisnis dan Manajemen, 5(2), 11-21.

Rismawan, E. (2015). The relationship between principa supervision and teacher achievement motivation on teacher teaching performance. Jurnal Administrasi Pendidikan, 22(1), 114-132.

Ross, J. A., \& Gray, P. (2006). School Leadership and Student Achievement: The Mediating Effect of Teacher Beliefs. Canadian Journal of Education, 29(3), 798-822.

Sagala, S. (2017). Concept and Meaning of Learning in the Educational Profession. Bandung: Alfabeta.

Septian, R., Ngadiman, \& Ivada, E. (2013). The influence of principal leadership and work motivation on teacher performance at SMP Negeri Wonosari. Jurnal Pendidikan Universitas Negeri Semarang, 2(1), 107-118.

Shatzer, R. H., Caldarella, P., Hallam, P. R., \& Brown, B. L. (2014). Comparing the effects of instructional and transformational leadership on student achievement: Implications for practice. Educationa Management Administration \& Leadership, 42(4), 445-459. . doi:https://doi.org/10.1177/1741143213502192

Sobirin. (2012). Factors that influence the teaching performance of elementary school teachers (Analytical Descriptive Study of the Influence of Principal leadership, School Climate, Job Satisfaction, and Achievement Motivation) on Teaching Performance of Elementary Schoo. Jurnal Administrasi Pendidikan, 14(1), 1-10.
Suarsana, I. K. (2009). Contribution of principal leadership behavior, teacher morale towards improving public high school teachers' performance in Gianyar Regency. Undiksha: -

Sudirjo, F. (2013). The Effect of Principal Supervision and Leadership on Motivation for Improving Teacher Performance. Jurnal Serat Acitya, 18(3), 30-35.

Suhaimi. (2018). Relationship between the role of the proncipal and attitudes towards the teaching proession with teacher work performance in public high school in the southern Hulu Sungai Regency. Jurnal IImiah Kependidikan 13(5), 78-83.

Suhaimi, \& Wardaniah. (2017). The relationship between principal supervision and achievement motivation with the performance of public SD teachers in Tanjung Subdistrict, Tabalong Regency. Prosiding Seminar Nasional S2DMP, 1-6.

Sulisworo, D., Nasir, R., \& Maryani, I. (2017). dentification of teachers' problems in Indonesia on facing global community. International Journal of Research Studies in Education, 6(2), 81-90. doi: 10.5861/ijrse.2016.1519

Suriansyah, A. (2015). The Leadership Strategies of School Proncipals, Parents, and Communicative in the building the Students Characters. Jurnal Cakrawala Pendidikan, 34(2), 1-6.

Suwedana, Natajaya, N., \& Sunu, G. K. (2013). Contribution of Principal Leadership, Achievement Motivation, and Job Satisfaction on Teacher Performance (Study of Perceptions of Teachers of SMK Negeri 1 Bangli). eJournal Program Pascasarjana Universitas Pendidikan Ganesha, 1-7.

UNESCO. (2018). Global Education Monitoring (GEM) Report . Paris: United Nations Educational, Scientific and Cultural Organization.

Wardana, L. W. (2008). Analisis pengaruh motivasi kerja, disiplin kerja, pendidikan dan pelatihan terhadap kinerja guru sekolah dasar negeri di kecamatan Gayungan kota Surabaya. Jurnal Ekonomi dan Bisnis (EMAS), 11(1), 1525.

Wijania, I. W. (2017). Kontribusi Kepemimpinan Pelayanan Kepala Sekolah, Motivasi Kerja, dan Disiplin Kerja Terhadap Kinerja Guru. Jurnal IImiah Pendidikan dan Pembelajaran PPs Universitas Pendidikan Ganesha Vol (1) 3, 176-184.

Wilson, M. B., \& Gardner, R. C. (2009). Teachers' motivation, classroom strategy use, students' motivation and second language achievement. Porta Linguarum, 12, 25-36. 